\title{
How much do we know about the coupling of G-proteins to serotonin receptors?
}

\author{
Matteo Giulietti ${ }^{1 \dagger}$, Viviana Vivenzio ${ }^{2 \dagger}$, Francesco Piva $^{1 *}$, Giovanni Principato ${ }^{1}$, Cesario Bellantuono ${ }^{2}$ \\ and Bernardo Nardi ${ }^{2}$
}

\begin{abstract}
Serotonin receptors are G-protein-coupled receptors (GPCRs) involved in a variety of psychiatric disorders. G-proteins, heterotrimeric complexes that couple to multiple receptors, are activated when their receptor is bound by the appropriate ligand. Activation triggers a cascade of further signalling events that ultimately result in cell function changes. Each of the several known G-protein types can activate multiple pathways. Interestingly, since several G-proteins can couple to the same serotonin receptor type, receptor activation can result in induction of different pathways. To reach a better understanding of the role, interactions and expression of G-proteins a literature search was performed in order to list all the known heterotrimeric combinations and serotonin receptor complexes. Public databases were analysed to collect transcript and protein expression data relating to G-proteins in neural tissues. Only a very small number of heterotrimeric combinations and G-protein-receptor complexes out of the possible thousands suggested by expression data analysis have been examined experimentally. In addition this has mostly been obtained using insect, hamster, rat and, to a lesser extent, human cell lines. Besides highlighting which interactions have not been explored, our findings suggest additional possible interactions that should be examined based on our expression data analysis.
\end{abstract}

Keywords: G-Proteins, Serotonin receptors, Protein expression, Nomenclature

\section{Introduction}

In normal physiology, the neurotransmitter serotonin (5-hydroxytryptamine, 5-HT) and its receptors regulate behaviours such as aggressiveness, anxiety, sex, sleep, mood, learning, cognition and memory. They are involved in numerous disease states, including depression, anxiety, social phobia, schizophrenia, mania, autism, drug addiction, obesity, obsessive-compulsive, panic and eating disorders. Therefore serotonin receptors are the target of a variety of pharmaceutical drugs. With the exception of the 5-HT3 receptor, a ligand-gated ion channel, serotonin receptors are a group of membrane-bound G-protein-coupled receptors, which, by means of G-proteins, activate intracellular pathways to produce an excitatory or inhibitory response [1].

G-proteins are heterotrimers consisting of three subunits: $\mathrm{G} \alpha, \mathrm{G} \beta$ and $\mathrm{G} \gamma$; they are located on the inner plasma

\footnotetext{
* Correspondence: f.piva@univpm.it

${ }^{\dagger}$ Equal contributors

'Department of Specialized Clinical Sciences and Odontostomatology,

Polytechnic University of Marche, Ancona, Italy

Full list of author information is available at the end of the article
}

membrane, from which they induce GPCR activation. The G $\beta$ and $G \gamma$ subunits form an inseparable complex, the $\beta \gamma$ complex [2]. In the absence of receptor stimulation the Go subunit binds guanosine diphosphate (GDP) and the $\beta \gamma$ complex, and remains dissociated from the receptor. Binding of the ligand to the GPCR domain outside the cell induces conformational changes of the intracellular GPCR domain, giving rise to GPCR coupling to the $G$ heterotrimer. Consequently, the $G \alpha$ protein exchanges GDP for guanosine triphosphate (GTP), causing dissociation of the GTP-bound $\alpha$-subunit from the $\beta \gamma$ complex and their separation from the activated receptor. $G \alpha$ and $\beta \gamma$ therefore activate a cascade of further signalling events that finally result in a change in cell function. The process

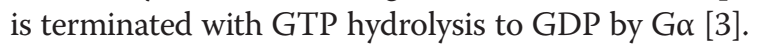

Various $G \alpha$ families have been described: they can activate different pathways or even exert opposite effects on the same pathway. In general, the $5-\mathrm{HT} 1(1 \mathrm{~A}, 1 \mathrm{~B}$, $1 \mathrm{D}, 1 \mathrm{E}, 1 \mathrm{~F})$ receptor family and 5 -HT5 receptors couple with Gai/o protein family to inhibit adenylate ciclase (AC) activity, reducing the intracellular cyclic adenosine 
monophosphate (cAMP) level whilst the Gas family 5coupled to HT4, 5-HT6 and 5-HT7 receptors triggers a pathway that leads to AC activation and cAMP production. The 5-HT2 (2A, 2B, 2C) receptor family couple with $\mathrm{G \alpha q} / 11$ proteins and stimulate the activity of phospholipase C (PLC) increasing the intracellular inositol trisphosphate (IP3), diacyl-glycerol (DAG) and $\mathrm{Ca}^{2+}$ levels [1]. However Goq can also indirectly alter cAMP production, by decreasing Gos protein abundance [4] or by activating adenylate cyclase 8 (ADCY8) by the PLC/Ca ${ }^{2+} /$ calmodulin pathway [5]. Moreover, the Goi/o family induces a decrease in intracellular cAMP levels through AC inhibition.

The G $\beta$ and Gy subunits are closely associated forming a $\beta \gamma$ complex that can be separated only by denaturation, except in cases when the complex involves $\beta 5$, whose bond to $\gamma$ subunits is much weaker. At variance with previous studies, the $\beta \gamma$ complex does not remain inert after dissociation from the $\alpha$ subunit, but plays a key role both in the inactive and in the active receptor state [6]. The $\beta \gamma$ complex has the following functions: i) it is required for optimal receptor-G-protein interaction, because it enhances ligand affinity and receptor-G-protein coupling, hence G-protein activation [7]; ii) its subunit composition affects receptor-G-protein coupling specificity $[8,9]$; iii) it activates specific pathways regardless of the type of $\mathrm{G \alpha}$ subunit involved [10]. The role of $\gamma$ subunits is to transport the $\beta \gamma$ complex from the endoplasmic reticulum to the plasma membrane. Although all $\gamma$ proteins share this property, translocation kinetics differs widely among subunits, ranging from $10 \mathrm{sec}$ of the fastest, $\gamma 9$, to several minutes of the slowest, $\gamma 3$ [11]. It may be hypothesized that the $\gamma$ subunits allowing fast translocation are associated with human serotonin receptors with a quicker turnover.

\section{Review}

\section{Many G-protein isoforms, huge number of possible} heterotrimers

We have explored UniProt (www.uniprot.org) and Entrez Gene (www.ncbi.nlm.nih.gov/gene) databases to establish how many protein isoforms are currently known for each G-protein subtype (Table 1). For example, we have found 10 isoforms of the Goi2 subtype. Generally, the isoforms do not derive from new gene loci but from different gene expression regulation of the main transcript. In particular, they are due to alternative splicing, use of alternative transcription start sites (TSS) and alternative start codons. All these detailed data are reported in Additional file 1 along with some annotations. In brief, we found many more protein isoforms than expected: $G \alpha, G \beta$, and $G \gamma$ proteins may actually be as many as 53,38 , and 20 , respectively, raising the potential heterotrimers to about 40,000 combinations. Most of the isoforms we reported are shorter and lack one or more functional domains compared to
Table 1 G-protein isoforms

\begin{tabular}{|c|c|c|c|}
\hline $\begin{array}{l}\text { Protein } \\
\text { name }\end{array}$ & Gene name & $\begin{array}{l}\text { Validated at } \\
\text { protein level }\end{array}$ & $\begin{array}{c}\text { Validated at } \\
\text { transcript level }\end{array}$ \\
\hline \multicolumn{4}{|c|}{ G alpha proteins } \\
\hline Gai1 & GNAl1 & 2 & - \\
\hline Gai2 & GNAI2 & 4 & 6 \\
\hline Gai3 & GNAI3 & 1 & - \\
\hline Ga11 & GNA11 & 1 & - \\
\hline Ga12 & GNA12 & 1 & 5 \\
\hline Ga13 & GNA13 & 1 & 2 \\
\hline Ga14 & GNA14 & - & 1 \\
\hline $\begin{array}{l}\text { Ga15 (or } \\
\text { Ga16) }\end{array}$ & GNA15 & 1 & 2 \\
\hline Gaolf & GNAL & 3 & 1 \\
\hline Gao & GNAO & 2 & 1 \\
\hline Gaq & GNAQ & 1 & 2 \\
\hline Gas & GNAS & 7 & 4 \\
\hline Gat1 & GNAT1 & 1 & - \\
\hline Gat2 & GNAT2 & 1 & - \\
\hline Gat3 & GNAT3 & - & 1 \\
\hline Gaz & GNAZ & - & 2 \\
\hline \multicolumn{4}{|c|}{$\mathrm{G}$ beta proteins } \\
\hline $\mathrm{G} \beta 1$ & GNB1 & 1 & 2 \\
\hline Gß1-like & GNB1L & 1 & 1 \\
\hline $\mathrm{G} \beta 2$ & GNB2 & 1 & 2 \\
\hline Gß2-like & GNB2L1 & 1 & 17 \\
\hline $\mathrm{G} \beta 3$ & GNB3 & 1 & 3 \\
\hline $\mathrm{G} \beta 4$ & GNB4 & 1 & 1 \\
\hline Gß5 & GNB5 & 3 & 3 \\
\hline \multicolumn{4}{|c|}{ G gamma proteins } \\
\hline Gy1 & GNGT1 & - & 2 \\
\hline Gy2 & GNG2 & 1 & 5 \\
\hline Gy3 & GNG3 & - & 1 \\
\hline Gy4 & GNG4 & 1 & - \\
\hline Gy5 & GNG5 & 1 & - \\
\hline Gy7 & GNG7 & 1 & 1 \\
\hline Gy8 & GNG8 (alias GNG9) & - & 1 \\
\hline Gy10 & GNG10 & 1 & - \\
\hline Gү11 & GNG11 & 1 & - \\
\hline Gy12 & GNG12 & 1 & - \\
\hline Gy13 & GNG13 & - & 1 \\
\hline Gyt2 & $\begin{array}{c}\text { GNGT2 (alias GNG8 or } \\
\text { GNG9) }\end{array}$ & - & 2 \\
\hline
\end{tabular}

For each human G-protein, it is shown the number of the related isoforms subdivided by the validation status, according to UniProt. Note that, GNA15 is the homolog gene encoding the murine Ga15 and the human Ga16 [13]. 
the reference isoforms, so they could have a reduced functional activity. In particular, the shorter Ga subtype isoforms lack GTP domains, the Gßs lack WD domains whereas the Gys have no alterations lying in their functional domains. Surprisingly, up till now, many isoforms have not yet been confirmed at protein level according to UniProt, so we looked for this information in the literature. Unfortunately, the papers merely report the name of the investigated G-protein and do not specify its particular isoform. We also found nomenclature inaccuracies, which are probably due to the former names of G-protein: for example when the authors write "the Goq protein" it is unclear whether they mean GNAQ (Goq) or the entire family including also GNA11 (Goq11),

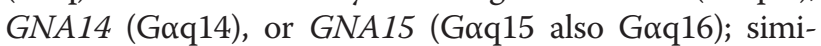
larly, "Goi protein" may indicate GNAI1 (Goi1), GNAI2

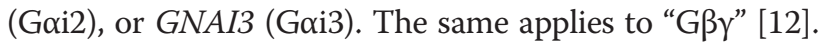
The nomenclature is not univocal even in some databases. For example, in UniProt GNG8 is also called GNG9, and GNGT2 is also called GNG8 or GNG9; therefore a paper examining GNG9 could refer either to GNG8 or to GNGT2. To overcome this ambiguity, the authors should indicate the protein or gene identifier or protein sequence.

\section{How heterotrimer composition affects 5-HT receptor behaviour}

The mechanisms underpinning formation of one heterotrimer rather than another are poorly understood, but posttranslational modifications of G-proteins and of membrane environments are likely to be involved [14]. Nonetheless heterotrimer composition is critical, because it determines what pathway is activated. For example, activation of 5HT1A receptor inhibits basal phosphoinositide hydrolysis in the dorsal raphe nucleus but not in the hippocampus, most likely due to different heterotrimer compositions in the two tissues [15]. Moreover a single heterotrimer can activate multiple pathways simultaneously, because some $\mathrm{G} \alpha$ proteins have multiple effects. For example, some Goi/ o family proteins inhibit AC leading to intracellular cAMP reduction, whereas others can also inhibit $\mathrm{Ca}^{2+}$ or activate $\mathrm{K}+$ channels [16]. To complicate matters further, the same serotonin receptor can couple to different heterotrimers $[7,17,18]$; the same ligand may therefore simultaneously activate multiple pathways but be unable to regulate a specific one. The mechanism appears to be irrational, since a single switch (receptor) is unlikely to be able to control a large number of lights (pathways).

Ligand-receptor binding affinity affects G-proteinreceptor affinity and vice versa, as described in Spodoptera frugiperda Sf9 cells [7]. Such affinity also depends on heterotrimeric composition; for example, coupling of Goi3 to 5-HT1A or 5-HT1B receptor was more effective than that of Goi2 and Goo in enhancing agonist $\left[{ }^{3} \mathrm{H}\right]-$ 5-HT affinity [14].
Since a variety of psychiatric disorders and/or drug responses are held to be related to altered ligand-receptor affinity, association studies have mainly explored receptor and downstream effector polymorphisms to explain the genetic basis of such different phenotypes [19-26]. However, given that G-proteins can affect ligand affinity, their variations should also be considered in association studies. For these reasons it is important to gain insights into the role, the interactors and the expression of G-proteins in determining cell responses as a consequence of receptor activation.

The observations that in some GPCRs the G-protein complex can modulate receptor activity state and that the transition from active to inactive state depends on the $G \alpha$ subunit associated with the receptor make the study of G-proteins even more intriguing [14]. In other words, GPCRs can switch from inactive to active even in the absence of binding to an agonist. This mechanism is still poorly understood and may have important pathological as well as physiological implications. In particular significant activation even without serotonin has been described with coupling of Goz to 5-HT1A receptor, but not to the other 5-HT1 receptors [27].

Finally, a scenario is emerging where different G-protein combinations can bind the same receptor type, conferring a different ligand affinity and activating several pathways. This warrants investigation of the heterotrimeric combinations that may form in humans, their distribution in different tissues, and the differences in ligand binding affinity among the heterotrimers resulting from binding of one receptor type and various G-proteins.

\section{How many couplings between 5-HT receptors and G- proteins are known}

In order to find out what is known about heterotrimer associations with serotonin GPCRs, we have performed a literature search. The papers specifically addressing receptor-G-protein complexes were scanty, therefore data were available for quite a small number of complexes out of the possible thousands. Table 2 presents an exhaustive list of all known combinations of the three types of Gproteins and their associations with serotonin receptors in human neural tissues or in similar models. In particular, for each receptor, we have reported the experimentally assessed complexes formed with the G-proteins, the tissues or contexts where the complexes were determined and their references. We have also annotated the couplings assessed as not present along with the particular experimental context. The 5-HT1p and 5-HT3 receptors were excluded, because the former is expressed in the nervous enteric system (not the central nervous system), the latter because it is a serotonin-gated ion channel not coupled to G-proteins, whereas 5-HT5B is 
Table 2 Assessed couplings between G-proteins and serotonin receptors

\begin{tabular}{|c|c|c|c|c|}
\hline $\begin{array}{l}\text { Coupling } \\
\text { G subunits }\end{array}$ & $\begin{array}{l}\text { Not coupling } \\
\text { G subunits }\end{array}$ & Notes & Second messengers & References \\
\hline & & 5-HT1A receptor & & \\
\hline Gas-?-? & & In guinea pig hippocampus & - & (Shenker, 1987) [28] \\
\hline \multicolumn{5}{|l|}{ Gai1-?-? } \\
\hline Gai2-?-? & \multirow{3}{*}{ No(Gas-?-?) } & \multirow{3}{*}{$\begin{array}{l}\text { Human receptor and bovine G-proteins, in vitro reconstitution into } \\
\text { E. coli membranes. Affinity order is Gai3 > Gai1 > Gai2 > }>\text { Gao. }\end{array}$} & \multirow{3}{*}{-} & \multirow{3}{*}{ (Bertin, 1992) [29] } \\
\hline Gai3-?-? & & & & \\
\hline \multirow{2}{*}{\multicolumn{5}{|c|}{$\begin{array}{l}\text { Gao-!-? } \\
\text { Gai1-?-? }\end{array}$}} \\
\hline & & & & \\
\hline Gai2-?-? & \multirow[t]{2}{*}{ No(Gas-?-?) } & \multirow{2}{*}{$\begin{array}{l}\text { Human receptor transfected in human HeLa and hamster } \\
\mathrm{CHO} \text { cells; affinity order is Gai3 > Gai2 > Gai1 }\end{array}$} & \multirow[t]{2}{*}{ CAMP } & \multirow[t]{2}{*}{ (Raymond, 1993) [30] } \\
\hline \multirow{2}{*}{\multicolumn{5}{|c|}{$\frac{\text { Gai3-?-? }}{\text { Gais-2-? }}$}} \\
\hline Gai2-?-? & & & & \\
\hline Gai3-?-? & & Human receptor transfected in hamster $\mathrm{CHO}$ cells & CAMP & (Gettys, 1994) [31] \\
\hline \multirow{4}{*}{ Gao-?-? } & No(Gas-?-?) & \multirow{4}{*}{ Human receptor transfected in insect Sf9 cells } & \multirow{4}{*}{-} & \multirow{4}{*}{ (Mulheron, 1994) [17] } \\
\hline & No(Gai1-?-?) & & & \\
\hline & No(Gai2-?-?) & & & \\
\hline & No(Gai3-?-?) & & & \\
\hline \multicolumn{5}{|l|}{ Gai1-Gß1-GY1 } \\
\hline \multicolumn{5}{|l|}{ Gai1-Gß1-Gy2 } \\
\hline \multicolumn{5}{|l|}{ Gai1-Gß1-Gy3 } \\
\hline Gai1-Gß1-Gү5 & & \multirow{6}{*}{ 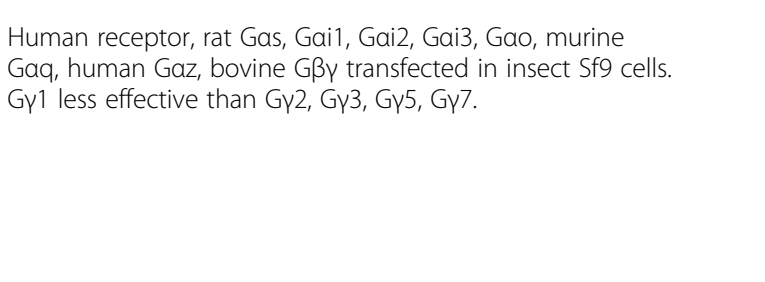 } & \multirow{6}{*}{-} & \multirow{6}{*}{ (Butkerait, 1995) [7] } \\
\hline Gai1-Gß1-GY7 & No(Gas-Gß1-Gү2) & & & \\
\hline Gai2-Gß1-Gy2 & No(Gaq-Gß1-Gү2) & & & \\
\hline \multirow{3}{*}{\multicolumn{2}{|c|}{ Gai3-Gß1-Gy2 }} & & & \\
\hline & & & & \\
\hline & & & & \\
\hline \multirow{3}{*}{ 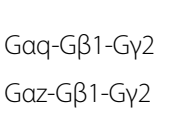 } & No(Ga12-Gß1-Gү2) & \multirow{3}{*}{$\begin{array}{l}\text { Human receptor, rat Gas, murine Gaq, human Gaz, bovine } \\
\text { GßY transfected in insect Sf9 cells; weak coupling with Gaq }\end{array}$} & \multirow{3}{*}{-} & \multirow{3}{*}{$($ Barr, 1997) [27] } \\
\hline & No(Ga13-Gß1-Gү2) & & & \\
\hline & No(Gas-Gß1-Gү2) & & & \\
\hline \multicolumn{5}{|l|}{ Gai1-?-? } \\
\hline Gai2-?-? & & & & \\
\hline Gai3-?-? & & $\begin{array}{l}\text { Human receptor and G-proteins transfected in hamster } \mathrm{CHO} \\
\text { cells, affinity order is Gai2 > Gai3, Gai1, Gao > Gaz }\end{array}$ & - & (Garnovskaya, 1997) [32] \\
\hline Gao-?-? & & & & \\
\hline Gaz-?-? & & & & \\
\hline
\end{tabular}


Table 2 Assessed couplings between G-proteins and serotonin receptors (Continued)

\begin{tabular}{|c|c|c|c|c|}
\hline Gai1-?-? & & \multirow{4}{*}{ Human receptor and rat Gas transfected in insect Sf9 cells } & \multirow{4}{*}{-} & \multirow{4}{*}{ (Clawges, 1997) [14] } \\
\hline Gai2-?-? & & & & \\
\hline Gai3-?-? & & & & \\
\hline \multicolumn{2}{|l|}{ Gao-?-? } & & & \\
\hline \multicolumn{2}{|l|}{ Gaz-Gß1-Gy2 } & Human receptor and G-proteins transfected in Sf9 cells & - & (Barr, 1997) [33] \\
\hline \multicolumn{2}{|l|}{ Gai1-?-? } & Rat receptor and G-proteins transfected in rat GH4C1 cells. & CAMP & (Liu, 1999) [34] \\
\hline \multirow{2}{*}{\multicolumn{2}{|c|}{$\begin{array}{l}\text { Gai2-?-? } \\
\text { Gai3-?-? }\end{array}$}} & \multirow{2}{*}{$\begin{array}{l}\text { Human receptor and G-proteins transfected in human HeLa } \\
\text { cells, affinity order is Gai1 > Gai2 > > Gai3 }\end{array}$} & \multirow{2}{*}{ - } & \multirow{2}{*}{$(\operatorname{Lin}, 2002)[35]$} \\
\hline & & & & \\
\hline Gai3-?-? & No(Gai1-?-?) & & & \\
\hline \multirow[t]{2}{*}{ Gai2-?-? } & No(Gai3-?-?) & \multirow[t]{2}{*}{ Rat receptor and G-proteins transfected in human HEK293 cells } & \multirow[t]{2}{*}{ CAMP } & \multirow[t]{2}{*}{ (Albert, 1999) [36] } \\
\hline & No(Gao-?-?) & & & \\
\hline \multicolumn{2}{|l|}{ Gaz-?-? } & In rat hypothalamic paraventricular nucleus & - & (Serres, 2000) [37] \\
\hline \multicolumn{2}{|l|}{ Gai/o-?-? } & \multirow{2}{*}{ Human receptor transfected in human HEK293 cells. } & \multirow{2}{*}{ CAMP } & \multirow{2}{*}{ (Malmberg, 2000) [38] } \\
\hline \multicolumn{2}{|l|}{ Gas-?-? } & & & \\
\hline \multirow[t]{2}{*}{ Gai3-?-? } & & $\begin{array}{l}\text { Human receptor co-expressed with rat G-protein in monkey COS-7 } \\
\text { cells. }\end{array}$ & - & (Dupuis, 2001) [39] \\
\hline & & Human receptor transfected in hamster $\mathrm{CHO}$ cells. & - & (Newman-Tancredi, 2002) [40] \\
\hline Gai1-?-? & No(Gat-?-?) & $\begin{array}{l}\text { Reconstitution in insect Sf9 cell expressing receptor and } \\
\text { rat Gai1 and bovine Gat }\end{array}$ & - & (Slessareva, 2003) [41] \\
\hline Gaq-Gß1-Gү2 & & \multirow{2}{*}{$\begin{array}{l}\text { Recombinant human receptor, mouse Gaq, rat Gai2, bovine } \\
\text { GßY co-expressed in insect Sf9. Strong coupling with Gai2, } \\
\text { weak with Gaq. }\end{array}$} & \multirow[b]{2}{*}{-} & \multirow{2}{*}{ (Okada, 2004) [42] } \\
\hline Gai2-Gß1-Gy2 & & & & \\
\hline \multirow[t]{2}{*}{ Gai/o-?-? } & No(Gaq-?-?) & $\begin{array}{l}\text { In situ reconstitution in insect Sf9 cells with purified human } \\
\text { receptor, squid Gaq, bovine Gai and Gao }\end{array}$ & - & (Okada, 2004) [42] \\
\hline & No(Gai1-?-?) & \multirow{4}{*}{ In rat cortex } & \multirow{4}{*}{-} & \multirow{4}{*}{ (Mannoury la Cour, 2006) [43] } \\
\hline Gao-?-? & No(Gai2-?-?) & & & \\
\hline \multirow[t]{2}{*}{ Gai3-?-? } & No(Gas-?-?) & & & \\
\hline & No(Gaz-?-?) & & & \\
\hline \multirow{5}{*}{ Gai3-?-? } & No(Gao-?-?) & & & \\
\hline & No(Gai1-?-?) & & & \\
\hline & No(Gai2-?-?) & In rat anterior raphe area & - & (Mannoury la Cour, 2006) [43] \\
\hline & No(Gas-?-?) & & & \\
\hline & No(Gaz-?-?) & & & \\
\hline Gao-?-? & No(Gas-?-?) & & & \\
\hline Gai1-?-? & No(Gaz-?-?) & In rat hippocampus & - & (Mannoury la Cour, 2006) [43] \\
\hline Gai3-?-? & No(Gai2-?-?) & & & \\
\hline
\end{tabular}


Table 2 Assessed couplings between G-proteins and serotonin receptors (Continued)

\begin{tabular}{|c|c|c|c|c|}
\hline Gao-?-? & & \multirow{4}{*}{ In rat hypothalamus } & \multirow{4}{*}{-} & \multirow{4}{*}{ (Mannoury la Cour, 2006) [43] } \\
\hline Gai1-?-? & No(Gas-?-?) & & & \\
\hline Gai3-?-? & No(Gai2-?-?) & & & \\
\hline \multicolumn{2}{|l|}{ Gaz-?-? } & & & \\
\hline \multicolumn{5}{|l|}{ Gao-?-? } \\
\hline Gai3-?-? & No(Gai1-?-?) & \multirow{3}{*}{ In rat hippocampus } & \multirow{3}{*}{-} & \multirow{3}{*}{ (Martel, 2007) [44] } \\
\hline Gas-?-? & & & & \\
\hline Gaq-?-? & & & & \\
\hline Gai2-?-? & No(Gas-?-?) & \multirow{3}{*}{ In rat dorsal raphe nucleus } & \multirow{3}{*}{ CAMP } & \multirow{3}{*}{ (Valdizán, 2010) [45] } \\
\hline Gai3-?-? & No(Gaz-?-?) & & & \\
\hline Gao-?-? & No(Gai1-?-?) & & & \\
\hline Gai2-?-? & & \multirow{2}{*}{ Human receptor transfected in hamster $\mathrm{CHO}$ cells } & \multirow{2}{*}{ CAMP } & \multirow{2}{*}{ (Rauly-Lestienne, 2011) [46] } \\
\hline \multirow[t]{2}{*}{ Gai3-?-? } & & & & \\
\hline & & \multicolumn{2}{|l|}{ 5-HT1B receptor } & \\
\hline \multicolumn{5}{|l|}{ Gai1-?-? } \\
\hline Gai2-?-? & & \multirow{3}{*}{ Human receptor and rat Ga transfected in insect Sf9 cells } & \multirow{3}{*}{-} & \multirow{3}{*}{ (Clawges, 1997) [14] } \\
\hline Gai3-?-? & & & & \\
\hline \multicolumn{2}{|l|}{ Gao-?-? } & & & \\
\hline \multirow{3}{*}{ Gai1-?-? } & & \multirow{3}{*}{$\begin{array}{l}\text { Reconstitution in insect Sf9 cell expressing receptor } \\
\text { and rat Gai1 and bovine Gat }\end{array}$} & - & \multirow{3}{*}{$\begin{array}{c}\text { (Bae, 1997; Bae, 1999; Slessareva, 2003) } \\
{[41,47,48]}\end{array}$} \\
\hline & No(Gat-?-?) & & - & \\
\hline & & & - & \\
\hline Gai2-?-? & & $\begin{array}{l}\text { Human receptor and rat G-proteins transfected in } \\
\text { human HEK293 cells }\end{array}$ & CAMP & (Albert, 1999) [36] \\
\hline \multirow{4}{*}{ Gai-?-? } & No(Gas-?-?) & \multirow{4}{*}{ Chimpanzee receptor transfected in human HEK293 cells } & \multirow{4}{*}{-} & \multirow{4}{*}{ (Alberts, 2000) [49] } \\
\hline & No(Gaq/11-?-?) & & & \\
\hline & No(Ga13-?-?) & & & \\
\hline & No(Gao-?-?) & & & \\
\hline Gai1-Gß1-Gy2 & & $\begin{array}{l}\text { Human receptor, rat Ga and bovine } G \beta \gamma \text { proteins transfected } \\
\text { in insect Sf9 cells }\end{array}$ & - & (Brys, 2000) [50] \\
\hline \multicolumn{5}{|c|}{ th } \\
\hline Gai2-?-? & & $\begin{array}{l}\text { Human receptor and G-proteins transfected in human } \\
\text { HeLa cells, affinity order is Gai1 > Gai2 >> Gai3 }\end{array}$ & - & $($ Lin, 2002) [35] \\
\hline \multicolumn{5}{|c|}{ ( } \\
\hline Gai3-?-? & & Human receptor transfected in hamster $\mathrm{CHO}$ cells & - & (Newman-Tancredi, 2003) [51] \\
\hline
\end{tabular}


Table 2 Assessed couplings between G-proteins and serotonin receptors (Continued)

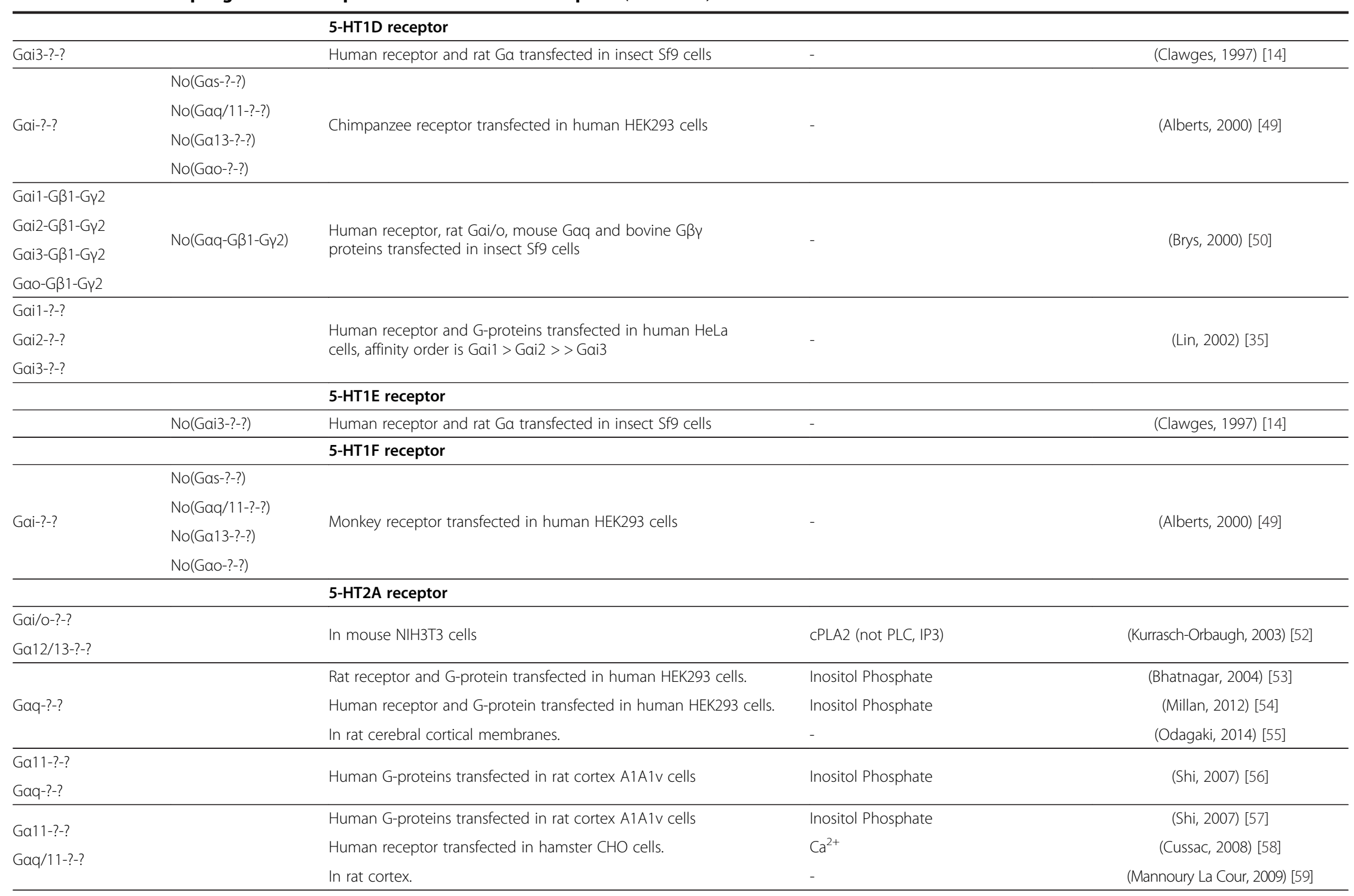


Table 2 Assessed couplings between G-proteins and serotonin receptors (Continued)

\begin{tabular}{|c|c|c|c|c|}
\hline & & 5-HT2B receptor & & \\
\hline \multicolumn{2}{|l|}{ Gaq/11-Gß1-Gү2 } & Mouse receptors stably expressed in mouse fibroblast cells & Ras & (Launay, 1996) [60] \\
\hline \multirow{3}{*}{ Ga13-?-? } & No(Gas-?-?) & \multirow{3}{*}{$\begin{array}{l}\text { In mouse LM6 and } 1 \mathrm{C} 11 \text { and in M. natalensis carcinoid } \\
\text { tumor primary cultured cells }\end{array}$} & \multirow{3}{*}{ IP3, NOS, cGMP } & \multirow{3}{*}{ (Manivet, 2000) [61] } \\
\hline & No(Gaq/11-?-?) & & & \\
\hline & No(Gai-?-?) & & & \\
\hline Gaq/11-?-? & & Human receptor transfected in hamster $\mathrm{CHO}$ cells & $\mathrm{Ca}^{2+}$ & (Cussac, 2008) [58] \\
\hline \multirow[t]{2}{*}{ Gaq-?-? } & & Human receptor and G-protein transfected in human HEK293 cells & Inositol Phosphate & (Millan, 2012) [54] \\
\hline & & \multicolumn{2}{|l|}{ 5-HT2C receptor } & \\
\hline \multicolumn{2}{|l|}{ Gai1-?-? } & \multirow{2}{*}{ Mouse receptor and rat G-proteins expressed in Xenopus oocytes } & \multirow{2}{*}{-} & \multirow{2}{*}{ (Chen, 1994) [62] } \\
\hline \multicolumn{2}{|l|}{ Gao-?-? } & & & \\
\hline Gao-?-? & No(Gas-?-?) & \multirow{3}{*}{ Mouse receptor and G-proteins expressed in Xenopus oocytes } & \multirow{3}{*}{ Inositol Phosphate } & \multirow{3}{*}{ (Quick, 1994) [63] } \\
\hline Gaq-?-? & No(Gaolf-?-?) & & & \\
\hline Ga11-?-? & No(Gat-?-?) & & & \\
\hline \multirow{2}{*}{ Gaq-?-? } & No(Gat-?-?) & \multirow{2}{*}{$\begin{array}{l}\text { Rat receptor and squid Gaq, bovine Gat, Gai/o proteins transfected } \\
\text { in insect Sf9 cells }\end{array}$} & \multirow{2}{*}{-} & \multirow{2}{*}{ (Hartman, 1996) [64] } \\
\hline & No(Gai/o-?-?) & & & \\
\hline \multirow{4}{*}{ Gai-?-? } & No(Gas-?-?) & \multirow{4}{*}{ Human receptor in human HEK293 cells } & \multirow{4}{*}{ IP3, CAMP } & \multirow{4}{*}{ (Alberts, 1999) [65] } \\
\hline & No(Gao-?-?) & & & \\
\hline & No(Gaq/11-?-?) & & & \\
\hline & No(Ga13-?-?) & & & \\
\hline Gaq-?-? & No(Gas-?-?) & In rat choroid plexus epithelial cells & Inositol Phosphate & (Chang, 2000) [66] \\
\hline \multirow{6}{*}{$\begin{array}{l}\text { Gaq-?-?*\# } \\
\text { Ga11-?-?\# } \\
\text { Ga13-?-?* } \\
\text { Ga15-?-?* }\end{array}$} & 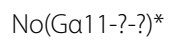 & \multirow{6}{*}{$\begin{array}{l}\text { Human receptor and mouse G-proteins (except human Ga16) } \\
\text { transfected in mouse NIH3T3 cells } \\
\text { * with not edited receptor form } \\
\text { \# with edited receptor form }\end{array}$} & \multirow{6}{*}{ Inositol Phosphate } & \multirow{6}{*}{ (Price, 2001) [67] } \\
\hline & \multirow{3}{*}{$\begin{array}{l}\mathrm{No}(\mathrm{Ga} 13-?-?)^{\#} \\
\mathrm{No}(\mathrm{Ga14}-?-?)^{* \#}\end{array}$} & & & \\
\hline & & & & \\
\hline & & & & \\
\hline & $\mathrm{No}(\mathrm{Ga15}$-?-?) & & & \\
\hline & No(Ga16-?-?) $)^{* \#}$ & & & \\
\hline Gai3-?-? & & \multirow{2}{*}{ Human receptor transfected in hamster $\mathrm{CHO}$ cells } & \multirow{2}{*}{-} & \multirow{2}{*}{ (Cussac, 2002) [68] } \\
\hline Gaq/11-?-? & & & & \\
\hline Gaq-?-? & $\mathrm{No}(G g s-2-?)$ & In rat choroid plexus epithelial cells and rat receptor transfected & Inositol Phosnhate (via PI D not PIO) & (McGrew 2002) [69] \\
\hline Ga13-?-? & Tho(Gas-?-?) & in mouse $\mathrm{NIH} 3 \mathrm{~T} 3$ cells & Inositor Pnospnate (VId PLU, nol PLC) & (IVICGIeW, LOUZ) [OY] \\
\hline & & Human receptor and squid G-protein reconstitution in insect Sf9 cells. & $\mathrm{Ca}^{2+}$ & (Okada, 2004) [70] \\
\hline Jay-!-!? & & Human receptor and G-protein transfected in human HEK293 cells. & Inositol Phosphate & (Millan, 2012) [54] \\
\hline
\end{tabular}


Table 2 Assessed couplings between G-proteins and serotonin receptors (Continued)

\begin{tabular}{|c|c|c|c|c|}
\hline \multirow{2}{*}{\multicolumn{2}{|c|}{$\begin{array}{l}\text { Gaq-Gß1-Gy2 } \\
\text { Gai2-Gß1-Gy2 }\end{array}$}} & \multirow{3}{*}{$\begin{array}{l}\text { Recombinant human receptor, mouse Gaq, rat Gai2, } \\
\text { bovine GBy co-expressed in insect Sf9. Strong coupling } \\
\text { with Gai2, weak with Gaq. } \\
\text { In situ reconstitution in insect Sf9 cells with purified human } \\
\text { receptor, squid Gaq, bovine Gai and Gao }\end{array}$} & \multirow{3}{*}{$\begin{array}{l}- \\
-\end{array}$} & \multirow{3}{*}{$\begin{array}{c}\text { (Okada, 2004) [42] } \\
\text { (Okada, 2004) [42] }\end{array}$} \\
\hline & & & & \\
\hline Gaq-?-? & No(Gai/o-?-?) & & & \\
\hline \multirow[t]{2}{*}{ Gaq/11-?-? } & & Human receptor transfected in hamster $\mathrm{CHO}$ cells & $\mathrm{Ca}^{2+}$ & (Cussac, 2008) [58] \\
\hline & & \multicolumn{2}{|l|}{ 5-HT4 receptor } & \\
\hline \multirow{4}{*}{ Gas-Gß1-Gү2 } & No(Gai2-Gß1-Gy2) & \multirow{4}{*}{ Murine receptor and G-proteins transfected in insect Sf9 cells } & \multirow{4}{*}{ CAMP } & \multirow{4}{*}{ (Ponimaskin, 2002) [71] } \\
\hline & No(Gai3-Gß1-Gy2) & & & \\
\hline & No(Ga12-Gß1-Gy2) & & & \\
\hline & No(Gaq-Gß1-Gy2) & & & \\
\hline \multirow{2}{*}{$\begin{array}{l}\text { Gas-?-? } \\
\text { Gai/o-?-? }\end{array}$} & & \multirow{2}{*}{$\begin{array}{l}\text { Human receptor transfected in human HEK293 cells; } \\
5 \text { HT4a receptor coupled only to Gas, while 5HT4b } \\
\text { isoform coupled to Gas and Gai/o }\end{array}$} & CAMP, $\mathrm{Ca}^{2+}$ & \multirow[b]{2}{*}{ (Pindon, 2002) [72] } \\
\hline & & & (not IP3) & \\
\hline \multirow{3}{*}{ 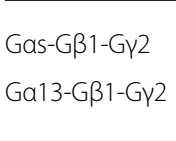 } & No(Gai2-Gß1-Gy2) & \multirow{3}{*}{ Murine receptor and G-proteins transfected in insect Sf9 cells } & \multirow{3}{*}{ Inositol Phosphate, RhoA } & \multirow{3}{*}{ (Ponimaskin, 2002) [73. } \\
\hline & No(Ga12-Gß1-Gy2) & & & \\
\hline & No(Gaq-GB1-Gү2) & & & \\
\hline \multirow[t]{3}{*}{ Gas-?-? } & & Human receptor transfected in monkey COS-7 cells & CAMP, Inositol Phosphate & (Pellissier, 2011) [74] \\
\hline & & \multicolumn{2}{|l|}{ 5-HT5A receptor } & \\
\hline & No(Gas-Gß1-Gү2) & \multirow{7}{*}{$\begin{array}{l}\text { Human receptor, rat Gai/o, human Gaz and Ga16, bovine } \\
\text { Gas, mouse Gaq, Ga11, Ga12 and Ga13, bovine G } \beta \gamma \\
\text { reconstituted in insect Sf9 cells }\end{array}$} & \multirow{7}{*}{-} & \multirow{7}{*}{ (Francken, 2000) [75] } \\
\hline Gai1-Gß1-GY2 & No(Gaz-Gß1-Gy2) & & & \\
\hline Gai2-Gß1-Gy2 & No(Gaq-Gß1-Gy2) & & & \\
\hline Gai3-Gß1-Gy2 & No(Ga11-Gß1-Gү2) & & & \\
\hline \multirow[t]{3}{*}{ Gao-Gß1-Gy2 } & $\mathrm{No}(\mathrm{Ga12}-\mathrm{G} \beta 1-\mathrm{G} \gamma 2)$ & & & \\
\hline & No(Ga13-Gß1-Gү2) & & & \\
\hline & $\mathrm{No}(\mathrm{Ga16}-\mathrm{G} \beta 1-\mathrm{G} \gamma 2)$ & & & \\
\hline \multicolumn{5}{|l|}{ Gai1-Gß1-Gү2 } \\
\hline Gai2-Gß1-Gү2 & No(Gas-Gß1-Gү2) & \multirow{3}{*}{$\begin{array}{l}\text { Human receptor, rat Gai/o, human Gaz, bovine Gas } \\
\text { and GBY reconstituted in insect Sf9 cells }\end{array}$} & \multirow{3}{*}{-} & \multirow{3}{*}{ (Francken, 2001) [76] } \\
\hline Gai3-Gß1-Gy2 & No(Gaz-GB1-Gy2) & & & \\
\hline \multicolumn{2}{|l|}{ Gao-Gß1-Gy2 } & & & \\
\hline \multirow[t]{2}{*}{ Gai/o-?-? } & & Human receptor transfected in rat C6 glioma cells & $\mathrm{IP}, \mathrm{Ca}^{2+}, \mathrm{CAMP}, \mathrm{CADPR}$ & (Noda, 2003) [77] \\
\hline & & 5-HT6 receptor & & \\
\hline \multirow{2}{*}{ Gas-?-? } & & In human HEK293 cells stably expressing human receptor. & CAMP & (Baker, 1998) [78] \\
\hline & & Human receptor and G-protein, assessed in vitro. & CAMP & (Kang, 2005) [79] \\
\hline
\end{tabular}


Table 2 Assessed couplings between G-proteins and serotonin receptors (Continued)

\begin{tabular}{|c|c|c|c|c|}
\hline & & 5-HT7 receptor & & \\
\hline Gas-?-? & No(Gai-?-?) & In human HEK293 cells stably expressing human receptor & CAMP, $\mathrm{Ca}^{2+} /$ calmodulin & (Baker, 1998) [78] \\
\hline \multirow{2}{*}{ Gas-?-? } & No(Gaq/11-?-?) & \multirow{2}{*}{ Human receptor transfected in murine LM cells } & \multirow{2}{*}{ CAMP } & \multirow{2}{*}{ (Adham, 1998) [80] } \\
\hline & No(Gai-?-?) & & & \\
\hline \multirow{2}{*}{$\begin{array}{l}\text { Gas-?-? } \\
\text { Gai-?-? }\end{array}$} & & \multirow{3}{*}{$\begin{array}{l}\text { Human receptor transfected in human HEK293 cells, } \\
\text { affinity order is Gas > Gai = Gaq/11 }\end{array}$} & \multirow{3}{*}{ CAMP } & \multirow{3}{*}{ (Alberts, 2001) [81] } \\
\hline & No(Gao-?-?) & & & \\
\hline Gaq/11-?-? & 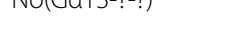 & & & \\
\hline \multirow{3}{*}{$\begin{array}{l}\text { Gas-Gß1-Gy2 } \\
\text { Ga12-Gß1-Gy2 }\end{array}$} & No(Gai2-Gß1-Gy2) & \multirow{3}{*}{$\begin{array}{l}\text { Murine receptor and G-proteins transfected in } \\
\text { insect Sf9 cells }\end{array}$} & \multirow{3}{*}{ RhoA, Cdc42 (NOT Rac1) } & \multirow{3}{*}{ (Kvachnina, 2005) [82] } \\
\hline & No(Ga13-Gß1-Gү2) & & & \\
\hline & No(Gaq-Gß1-Gү2) & & & \\
\hline \multirow{3}{*}{$\begin{array}{l}\text { Gas-Gß1-Gy2 } \\
\text { Ga12-Gß1-Gy2 }\end{array}$} & No(Gaq-Gß1-Gү2) & \multirow{3}{*}{$\begin{array}{l}\text { Murine receptor and G-proteins transfected in } \\
\text { insect Sf9 cells }\end{array}$} & \multirow{3}{*}{ CAMP } & \multirow{3}{*}{ (Kvachnina, 2009) [83] } \\
\hline & No(Gai-Gß1-Gү2) & & & \\
\hline & No(Ga13-Gß1-Gy2) & & & \\
\hline
\end{tabular}

"?" means that the particular G $\beta$ or G $\gamma$ protein has not be identified in the reference paper. "-" means that the second messenger has not be assessed in the reference paper. Note: unfortunately some papers reported Gai/o, Gai, or Gaq/11 without further distinction. Abbreviations: RhoA: Ras homolog gene family, member A; Cdc42: cell division control protein 42; Rac1: Ras-related C3 botulinum toxin substrate 1; cADPR: cyclic adenosine diphosphoribose; PLD: phospholipase D; NOS: nitric-oxide synthase; cGMP: cyclic guanosine monophosphate; CPLA2: cytosolic phospholipases A2. 
a pseudogene in humans according to EntrezGene and the related protein is absent in UniProt.

Many papers have addressed G-protein combinations with 5-HT1A, 5-HT1B, 5-HT2A and 5-HT2C while only one or two papers refer to 5-HT1E, 5-HT1F or 5-HT6. The experimental models usually involve transfection of human genes into Spodoptera frugiperda Sf9 cells, since they express low levels of mammalian G-proteins, thus avoiding competition with endogenously expressed Gproteins in $\left[{ }^{35} \mathrm{~S}\right] \mathrm{GTP} \gamma \mathrm{S}$ binding assay [16].

However, to extend these findings to humans is not necessarily correct. For example, the poor coupling of Goq to 5-HT1A and 5-HT2C could be due to a large portion of the expressed but inactive Goq [84], maybe because Goq is not post-translationally modified by palmitoylation in Sf9 as in humans [85]. Other authors have used hamster, mouse and human cells transfected with rat, mouse and bovine constructs. The main methods used to assess the compositions of the heterotrimers are immunoprecipitation and western blot analysis, the binding with radio-ligands and FRET (Förster Resonance Energy Transfer) by using fluorescent ligands.

For the majority of serotonergic receptors, coupling data are available only in relation to $G \alpha$ family proteins without specifying which $G \beta$ and $G \gamma$ were coupled. However, the few data on $G \beta$ and $G \gamma$ only concerned

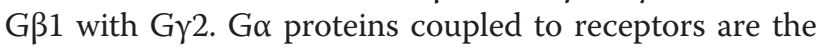
most commonly studied G-proteins, because they are held to indicate the pathway activated by receptor stimulation. In contrast, $G \beta$ and $G \gamma$ proteins are believed merely to play a structural role, that is to stabilize the receptor complex, but they actively participate in signal transduction by activating specific pathways.

We also annotated the second messengers activated downstream G-proteins, when these data were available in the related paper, since they allow to take into account the converging effect of various $G \alpha$ proteins and the antagonistic/additive effects of $\mathrm{G} \beta \gamma$.

\section{Investigation methods for the assessment of G-protein activation}

We have shown that G-protein heterotrimers recruited by serotonin receptors have been evaluated experimentally. This dearth of data is mainly due to the cumbersome methods used to identify the heterotrimers involved in the effects of ligands and to some technical limitations. In fact, to assess the receptor-mediated G-protein activation, both indirect and direct assays are available [16]. Indirect methods, in spite of their good sensitivity, are focused on measuring concentrations of second messengers but the evaluation of these data can be complicated since most receptors can activate different G-proteins.

In particular, since Gos and Goi/o proteins activate or inhibit AC respectively, their activation can be indirectly detected determining intracellular adenosine triphosphate (ATP) conversion into cAMP. It is measured using $\left[\alpha-{ }^{32} \mathrm{P}\right]$ ATP as the enzyme substrate or using cAMP antibodies. These methods cannot follow quick fluctuations as they are based on static measurements after cell lysis. In the case of the AC inhibiting Gai/o proteins, another problem regards the too low dynamic ranges of inhibition detection. To deal with this specific problem, chimeric Gai/o proteins were developed, but they do not exactly mimic the natural G-proteins.

To test ligand efficacy on Gaq/11-coupled receptors, $\left[{ }^{3} \mathrm{H}\right] \mathrm{IP} 3$ concentration as product of PLC activity can be measured using $\left[{ }^{3} \mathrm{H}\right] \mathrm{PIP} 2$ (phosphatidyl inositol 4,5bisphosphate) substrate. Alternatively, antibodies can be used, but, since IP3 has a short half life, it is preferred to detect its stable metabolite inositol-1-phosphate (IP1), although this is a more downstream product. Also $\mathrm{Ca}^{2+}$ concentration, by dyes generating fluorescence upon binding of free $\mathrm{Ca}^{2+}$, can be determined to assess $\mathrm{G} \alpha q / 11$ activation, although these probes can influence calcium levels and kinetics. Moreover, $\mathrm{Ca}^{2+}$-sensitive photoproteins, as aequorin, can detect calcium in specific cell compartments by fusion with targeting sequences. This approach is not so sensitive and consists of laborious procedures, such as fusion protein production, transfection and assay calibration.

Ga12/13 activation can be assessed by determining Rho guanine nucleotide exchange factors (RhoGEFs) by immunoblotting, a not highly sensitive technique. Moreover, since RhoGEFs are activated also by Goq/11, there are crosstalk problems that can be partially overcome by small interfering RNA (siRNA) knockdown.

To directly and quantitatively assess the $G \alpha$ protein activation, $\left[{ }^{35} \mathrm{~S}\right] \mathrm{GTP} \gamma \mathrm{S}$ binding assay is employed. Upon $\mathrm{G \alpha}$ subunit activation, it binds the mimic substrate, so remaining blocked in the active form as it cannot hydrolyze this substrate. The blocked $\mathrm{G} \alpha$ can be measured after isolation and it can be immunoprecipitated to identify the specific Go subunit. However, this approach is mainly suitable to evaluate Gai/o-coupled receptor activation. This assay can be effectively combined with the use of drugs stimulating or inhibiting specific G-proteins, for example, Pertussis toxin (PTX), Mastoparan, MastoparanS, Cholera toxin, Suramin, Pasteurella multocida toxin (PMT). Alternatively, it is possible to use G-proteindeficient mice or gene silencing by siRNA, although studies have to take into account the cellular compensatory mechanisms that alter the expression level of other G-proteins. An exhaustive review of these and other techniques was made by Denis et al. [16].

Moreover, cause of GTPase-accelerating proteins (GAPs) that accelerate GTPase activity of Go-protein subunits, the measuring of GTPase activity in vivo and in vitro differ. In addition, for in vivo studies, methods having a 
subsecond time resolution for GTP hydrolysis must be adopted $[86,87]$.

\section{Heterotrimers activation effects}

It would be important to consider the synergic effects of the entire activated heterotrimer in order to evaluate ligand effects, drug efficacy and side effects such as hallucination onset. For this reason, we annotated also the second messengers during literature revision. Unfortunately, as can be seen in Table 2, few studies assessed the coupling of all the heterotrimer subunits and few of them assessed the second messengers. Regarding these cases, only $G \beta 1 \gamma 2$ were present, so it was not possible to verify if and how different $G \beta \gamma$ combinations can affect $\mathrm{G} \alpha$ induced pathways. In general, the physiological significance of the different G $\beta \gamma$ pairs is unclear, since they participate in complex interactions with receptors, Go subunits and effectors [6].

A more detailed description of the pathway downstream G-proteins was performed by Millan et al. [88], however it should be taken into account that the signalling downstream a receptor is ligand-dependent. For example, some agonists of 5-HT2A can induce hallucinations but other structurally related ones do not [89].

\section{Expression analysis in human brain tissues}

We believe that our collected data can be used for guiding experiments which seek new couplings. However, we verified if it was possible to reduce the number of combinations by filtering out those not allowed in a particular neural tissue due to one or more components that are not expressed. In Additional file 2, we report the expression profiles of $\mathrm{G} \alpha, \mathrm{G} \beta, \mathrm{G} \gamma$ and the serotonin receptor by using three proteomic databases according to a previous work [90]: Human Protein Reference Database (www.hprd.org); Human Proteinpedia (www.humanproteinpedia.org) and Human Protein Atlas (www.proteinatlas.org). We also used expression data obtained from three transcriptomic databases: Human Transcriptome Map (http://bioinfo.amc.uva.nl/HTMseq), Cancer Gene Anatomy Project database (http://cgap.nci.nih.gov) and Allen Brain Atlas database (www.brain-map.org). An issue that arose in the course of this investigation was the partial conflict between microarray and RNA-Seq data retrieved from Allen Brain Atlas and, to a lesser extent, protein and transcript expression data. Generally, these discrepancies could be resolved by relying on proteomic data, which, if present, are usually more dependable than transcriptomic data. For example, regarding GNG1, it seems to be absent in all tissues and their sub-tissues assessed by Allen Brain Atlas RNA-seq. Instead, according to Allen Brain Atlas microarray data, GNG1 expression results as being very variable among sub-tissues of each tissue. Since in the cerebellar cortex also Protein Atlas data are available, they solve this contradiction claiming GNG1 absence. According to our expression data, most G-proteins are expressed in the majority of brain tissues, thus confirming the possible existence of a big number of heterotrimer combinations in nearly all neural tissues. Of course, co-expression of a receptor and G-proteins in a brain tissue does not imply that they are functionally coupled to each other. However, the available databases, being manually annotated, do not contain the all expression data reported in the literature, so the Additional file 2 may be incomplete.

\section{Conclusion}

The large number of human G-proteins that our searches found demonstrates that a very large amount of possible heterotrimers can be formed but unfortunately only a few have been assessed. Naturally, a limitation of the studies carried out in vitro is that the reported couplings do not always match to the couplings found in vivo [91]. However, knowledge of all the G-proteins that bind to each receptor would allow linking each receptor to all the possible activated pathways. Association of a receptor with multiple G-proteins would also highlight activation of different pathways in different tissues. This is important, because G-protein gene mutations or polymorphisms could alter transduction efficacy, thus explaining the non-activation of a pathway despite the presence of the right ligand and the absence of nucleotide variation in the receptor. Therefore precise knowledge of the role and distribution of G-proteins would greatly contribute to the evaluation of G-protein gene polymorphisms and to the development of drugs targeting specific G-proteins.

Finally, since receptor binding to a G-protein considerably modifies receptor behaviour, it could be that the G-proteins define many receptor subtypes. For this reason it is more appropriate to consider a receptor not individually but in association to each permitted heterotrimer. This also suggests that a number of experiments should be performed again, like the biochemical studies exploring the affinity constants between ligands and a receptor not considering if, and which, G-proteins were associated.

\section{Additional files}

Additional file 1: Detailed information about G-protein isoforms. In this table all G-protein isoforms along with annotations extracted from UniProt and EntrezGene are shown.

Additional file 2: G-protein and serotonin receptor expression data in brain subtissues. In this table G-protein and serotonin receptor expression data extracted from different transcriptomic and proteomic databases are shown.

\section{Abbreviations}

5-HT: Serotonin; GPCRs: G-protein-coupled receptors; GDP: Guanosine diphosphate; GTP: Guanosine triphosphate; AC: Adenylate cyclase; CAMP: Cyclic adenosine monophosphate; PLC: Phospholipase C; DAG: Diacyl- 
glycerol; IP3: Inositol trisphosphate; PKC: Protein kinase C; ADCY8: Adenylate cyclase 8; TSS: Transcription start sites; FRET: Förster resonance energy transfer; ATP: Adenosine triphosphate; PIP2: Phosphatidyl inositol 4,5bisphosphate; IP1: Inositol-1-phosphate; RhoGEF: Rho guanine nucleotide exchange factor; siRNA: Small interfering RNA; PTX: Pertussis toxin; PMT: Pasteurella multocida toxin; GAP: GTPase-accelerating protein.

\section{Competing interests}

The authors declare that they have no competing interests.

\section{Authors' contributions}

$M G, W$ and FP performed the analyses and wrote the manuscript. GP, CB and BN conceived of the study, and participated in its design and coordination. All authors read and approved the final manuscript.

\section{Author details}

'Department of Specialized Clinical Sciences and Odontostomatology, Polytechnic University of Marche, Ancona, Italy. ${ }^{2}$ Psychiatric Unit, Neurosciences Department, Polytechnic University of Marche, Ancona, Italy.

Received: 21 March 2014 Accepted: 27 June 2014

Published: 10 July 2014

\section{References}

1. Filip M, Bader M: Overview on 5-HT receptors and their role in physiology and pathology of the central nervous system. Pharmacol Rep 2009, 61:761-777.

2. Hurowitz EH, Melnyk JM, Chen YJ, Kouros-Mehr H, Simon Ml, Shizuya H: Genomic characterization of the human heterotrimeric $\mathrm{G}$ protein alpha, beta, and gamma subunit genes. DNA Res 2000, 7:111-120.

3. Oldham WM, Hamm HE: Heterotrimeric G protein activation by G-proteincoupled receptors. Nat Rev Mol Cell Biol 2008, 9:60-71.

4. Tang T, Gao MH, Miyanohara A, Hammond HK: Galphaq reduces CAMP production by decreasing Galphas protein abundance. Biochem Biophys Res Commun 2008, 377:679-684.

5. Twery EN, Raper JA: SDF1-induced antagonism of axonal repulsion requires multiple G-protein coupled signaling components that work in parallel. PLOS ONE 2011, 6:e18896.

6. Smrcka AV: G protein betagamma subunits: central mediators of $\mathrm{G}$ protein-coupled receptor signaling. Cell Mol Life Sci 2008, 65:2191-2214.

7. Butkerait $P$, Zheng $Y$, Hallak $H$, Graham TE, Miller HA, Burris KD, Molinoff PB, Manning DR: Expression of the human 5-hydroxytryptamine1A receptor in Sf9 cells. Reconstitution of a coupled phenotype by co-expression of mammalian G protein subunits. J Biol Chem 1995, 270:18691-18699.

8. Kisselev O, Gautam N: Specific interaction with rhodopsin is dependent on the gamma subunit type in a G protein. J Biol Chem 1993, 268:24519-24522.

9. Kleuss C, Scherubl H, Hescheler J, Schultz G, Wittig B: Selectivity in signal transduction determined by gamma subunits of heterotrimeric $G$ proteins. Science 1993, 259:832-834

10. Raymond JR, Mukhin YV, Gettys TW, Garnovskaya MN: The recombinant 5-HT1A receptor: $\mathrm{G}$ protein coupling and signalling pathways. $\mathrm{Br} J$ Pharmacol 1999, 127:1751-1764.

11. Ajith Karunarathne WK, O'Neill PR, Martinez-Espinosa PL, Kalyanaraman V, Gautam N: All G protein betagamma complexes are capable of translocation on receptor activation. Biochem Biophys Res Commun 2012, 421:605-611.

12. Glass M, Northup JK: Agonist selective regulation of $G$ proteins by cannabinoid $\mathrm{CB}(1)$ and $\mathrm{CB}(2)$ receptors. Mol Pharmacol 1999, 56:1362-1369.

13. Wilkie TM, Gilbert DJ, Olsen AS, Chen XN, Amatruda TT, Korenberg JR, Trask BJ, de Jong P, Reed RR, Simon Ml, et al: Evolution of the mammalian G protein alpha subunit multigene family. Nat Genet 1992, 1:85-91.

14. Clawges HM, Depree KM, Parker EM, Graber SG: Human 5-HT1 receptor subtypes exhibit distinct $\mathrm{G}$ protein coupling behaviors in membranes from Sf9 cells. Biochemistry 1997, 36:12930-12938.

15. Johnson RG, Fiorella D, Winter JC, Rabin RA: [3H]8-OH-DPAT labels a 5-HT site coupled to inhibition of phosphoinositide hydrolysis in the dorsal raphe. Eur J Pharmacol 1997, 329:99-106.

16. Denis C, Sauliere A, Galandrin S, Senard JM, Gales C: Probing heterotrimeric G protein activation: applications to biased ligands. Curr Pharm Des 2012, 18:128-144.
17. Mulheron JG, Casanas SJ, Arthur JM, Garnovskaya MN, Gettys TW, Raymond JR: Human 5-HT1A receptor expressed in insect cells activates endogenous $G$ (o)-like G protein(s). J Biol Chem 1994, 269:12954-12962.

18. Parker EM, Grisel DA, Iben LG, Nowak HP, Mahle CD, Yocca FD, Gaughan GT: Characterization of human 5-HT1 receptors expressed in Sf9 insect cells. Eur J Pharmacol 1994, 268:43-53.

19. Piva F, Giulietti M, Armeni T, Principato G: Cross-link immunoprecipitation data to detect polymorphisms lying in splicing regulatory motifs: a method to refine single nucleotide polymorphism selection in association studies. Psychiatr Genet 2012, 22:88-91.

20. Piva F, Giulietti M, Baldelli L, Nardi B, Bellantuono C, Armeni T, Saccucci F, Principato G: Bioinformatic analyses to select phenotype affecting polymorphisms in HTR2C gene. Hum Psychopharmacol 2011, 26:365-372.

21. Nardi B, Turchi C, Piva F, Giulietti M, Castellucci G, Arimatea E, Rochetti D, Rocchetti G, Principato G, Tagliabracci A, Bellantuono C: Searching for a relationship between the serotonin receptor $2 \mathrm{~A}$ gene variations and the development of inward and outward personal meaning organizations. Psychiatr Genet 2011, 21:269-270.

22. Piva F, Giulietti M, Nardi B, Bellantuono C, Principato G: An improved in silico selection of phenotype affecting polymorphisms in SLC6A4, HTR1A and HTR2A genes. Hum Psychopharmacol 2010, 25:153-161.

23. Nardi B, Piva F, Turchi C, Giulietti M, Castellucci G, Arimatea E, Rocchetti D, Rocchetti G, Principato G, Tagliabracci A, Bellantuono C: HTR2A gene polymorphisms and inward and outward personal meaning organisations. Acta Neuropsychiatrica 2012, 24:336-343.

24. Blasi G, De Virgilio C, Papazacharias A, Taurisano P, Gelao B, Fazio L, Ursini G, Sinibaldi L, Andriola I, Masellis R, Romano R, Rampino A, Di Giorgio A, Lo Bianco L, Caforio G, Piva F, Popolizio T, Bellantuono C, Todarello O, Kleinman JE, Gadaleta G, Weinberger DR, Bertolino A: Converging evidence for the association of functional genetic variation in the serotonin receptor $2 \mathrm{a}$ gene with prefrontal function and olanzapine treatment. JAMA Psychiatry 2013, 70:921-930.

25. Galeazzi R, Massaccesi L, Piva F, Principato G, Laudadio E: Insights into the influence of $5-\mathrm{HT} 2 \mathrm{C}$ aminoacidic variants with the inhibitory action of serotonin inverse agonists and antagonists. J Mol Model 2014, 20:2120.

26. Blasi G, Napolitano F, Ursini G, Di Giorgio A, Caforio G, Taurisano P, Fazio L, Gelao B, Attrotto MT, Colagiorgio L, Todarello G, Piva F, Papazacharias A, Masellis R, Mancini M, Porcelli A, Romano R, Rampino A, Quarto T, Giulietti M, Lipska BK, Kleinman JE, Popolizio T, Weinberger DR, Usiello A, Bertolino A: Association of GSK-3beta genetic variation with GSK-3beta expression, prefrontal cortical thickness, prefrontal physiology, and schizophrenia. Am J Psychiatry 2013, 170:868-876.

27. Barr AJ, Brass LF, Manning DR: Reconstitution of receptors and GTP-binding regulatory proteins ( $G$ proteins) in Sf9 cells. A direct evaluation of selectivity in receptor.G protein coupling. J Biol Chem 1997, 272:2223-2229.

28. Shenker A, Maayani S, Weinstein H, Green JP: Pharmacological characterization of two 5-hydroxytryptamine receptors coupled to adenylate cyclase in guinea pig hippocampal membranes. Mol Pharmacol 1987, 31:357-367.

29. Bertin B, Freissmuth M, Breyer RM, Schutz W, Strosberg AD, Marullo S: Functional expression of the human serotonin $5-\mathrm{HT} 1 \mathrm{~A}$ receptor in Escherichia coli. Ligand binding properties and interaction with recombinant G protein alpha-subunits. J Biol Chem 1992, 267:8200-8206.

30. Raymond JR, Olsen CL, Gettys TW: Cell-specific physical and functional coupling of human 5-HT1A receptors to inhibitory G protein alpha-subunits and lack of coupling to Gs alpha. Biochemistry 1993, 32:11064-11073

31. Gettys TW, Fields TA, Raymond JR: Selective activation of inhibitory G-protein alpha-subunits by partial agonists of the human 5-HT1A receptor. Biochemistry 1994, 33:4283-4290.

32. Garnovskaya MN, Gettys TW, van Biesen T, Prpic V, Chuprun JK, Raymond JR: 5-HT1A receptor activates $\mathrm{Na}+\mathrm{H}+$ exchange in $\mathrm{CHO}-\mathrm{K} 1$ cells through Gialpha2 and Gialpha3. J Biol Chem 1997, 272:7770-7776.

33. Barr AJ, Manning DR: Agonist-independent activation of $\mathrm{Gz}$ by the 5 hydroxytryptamine1A receptor co-expressed in Spodoptera frugiperda cells. Distinguishing inverse agonists from neutral antagonists. J Biol Chem 1997, 272:32979-32987.

34. Liu YF, Ghahremani MH, Rasenick MM, Jakobs KH, Albert PR: Stimulation of CAMP synthesis by Gi-coupled receptors upon ablation of distinct Galphai protein expression. Gi subtype specificity of the 5-HT1A receptor. J Biol Chem 1999, 274:16444-16450. 
35. Lin SL, Setya S, Johnson-Farley NN, Cowen DS: Differential coupling of 5-HT(1) receptors to $\mathrm{G}$ proteins of the G(i) family. Br J Pharmacol 2002, 136:1072-1078.

36. Albert PR, Sajedi N, Lemonde S, Ghahremani MH: Constitutive G(i2)dependent activation of adenylyl cyclase type II by the 5-HT1A receptor. Inhibition by anxiolytic partial agonists. J Biol Chem 1999, 274:35469-35474.

37. Serres F, Li Q, Garcia F, Raap DK, Battaglia G, Muma NA, Van de Kar LD: Evidence that $\mathrm{G}(\mathrm{z})$-proteins couple to hypothalamic 5-HT(1A) receptors in vivo. J Neurosci 2000, 20:3095-3103.

38. Malmberg A, Strange PG: Site-directed mutations in the third intracellular loop of the serotonin 5-HT(1A) receptor alter $G$ protein coupling from $G(i)$ to G(s) in a ligand-dependent manner. J Neurochem 2000, 75:1283-1293.

39. Dupuis DS, Wurch T, Tardif S, Colpaert FC, Pauwels PJ: Modulation of 5-HT (1A) receptor activation by its interaction with wild-type and mutant $\mathrm{g}$ (alphai3) proteins. Neuropharmacology 2001, 40:36-47.

40. Newman-Tancredi A, Cussac D, Marini L, Millan MJ: Antibody capture assay reveals bell-shaped concentration-response isotherms for h5-HT(1A) receptor-mediated Galpha(i3) activation: conformational selection by high-efficacy agonists, and relationship to trafficking of receptor signaling Mol Pharmacol 2002, 62:590-601.

41. Slessareva JE, Ma H, Depree KM, Flood LA, Bae H, Cabrera-Vera TM, Hamm HE, Graber SG: Closely related G-protein-coupled receptors use multiple and distinct domains on G-protein alpha-subunits for selective coupling. J Biol Chem 2003, 278:50530-50536.

42. Okada M, Goldman D, Linnoila M, Iwata N, Ozaki N, Northup JK: Comparison of G-protein selectivity of human 5-HT2C and 5-HT1A receptors. Ann N Y Acad Sci 2004, 1025:570-577.

43. la Cour Mannoury C, El Mestikawy S, Hanoun N, Hamon M, Lanfumey L: Regional differences in the coupling of 5-hydroxytryptamine-1A receptors to G proteins in the rat brain. Mol Pharmacol 2006, 70:1013-1021.

44. Martel JC, Ormiere AM, Leduc N, Assie MB, Cussac D, Newman-Tancredi A: Native rat hippocampal 5-HT1A receptors show constitutive activity. $\mathrm{Mol}$ Pharmacol 2007, 71:638-643.

45. Valdizan EM, Castro E, Pazos A: Agonist-dependent modulation of G-protein coupling and transduction of 5-HT1A receptors in rat dorsal raphe nucleus. Int J Neuropsychopharmacol 2010, 13:835-843.

46. Rauly-Lestienne I, Lestienne F, Ailhaud MC, Binesse J, Newman-Tancredi A, Cussac D: Competitive interaction of 5-HT(1A) receptors with G-protein subtypes in $\mathrm{CHO}$ cells demonstrated by RNA interference. Cell Signal 2011, 23:58-64.

47. Bae H, Anderson K, Flood LA, Skiba NP, Hamm HE, Graber SG: Molecular determinants of selectivity in 5-hydroxytryptamine1B receptor-G protein interactions. J Biol Chem 1997, 272:32071-32077.

48. Bae H, Cabrera-Vera TM, Depree KM, Graber SG, Hamm HE: Two amino acids within the alpha4 helix of Galphai1 mediate coupling with 5hydroxytryptamine1B receptors. J Biol Chem 1999, 274:14963-14971.

49. Alberts GL, Pregenzer JF, Im WB, Slightom JL: Cloning of serotonin 5-HT(1) receptor subtypes from the chimpanzee, gorilla and Rhesus monkey and their agonist-induced guanosine $5^{\prime}$ gamma(35)S triphosphate binding. Neurosci Lett 2000, 280:223-227.

50. Brys R, Josson K, Castelli MP, Jurzak M, Lijnen P, Gommeren W, Leysen JE: Reconstitution of the human 5-HT(1D) receptor-G-protein coupling: evidence for constitutive activity and multiple receptor conformations. Mol Pharmacol 2000, 57:1132-1141.

51. Newman-Tancredi A, Cussac D, Marini L, Touzard M, Millan MJ: h5-HT(1B) receptor-mediated constitutive Galphai3-protein activation in stably transfected Chinese hamster ovary cells: an antibody capture assay reveals protean efficacy of 5-HT. Br J Pharmacol 2003, 138:1077-1084.

52. Kurrasch-Orbaugh DM, Parrish JC, Watts VJ, Nichols DE: A complex signaling cascade links the serotonin $2 \mathrm{~A}$ receptor to phospholipase $\mathrm{A} 2$ activation: the involvement of MAP kinases. J Neurochem 2003, 86:980-991.

53. Bhatnagar A, Sheffler DJ, Kroeze WK, Compton-Toth B, Roth BL: Caveolin-1 interacts with 5 -HT2A serotonin receptors and profoundly modulates the signaling of selected Galphaq-coupled protein receptors. J Biol Chem 2004, 279:34614-34623.

54. Millan MJ, la Cour Mannoury C, Chanrion B, Dupuis DS, Di Cara B, Audinot V, Cussac D, Newman-Tancredi A, Kamal M, Boutin JA, Jockers R, Marin P, Bockaert J, Muller O, Dekeyne A, Lavielle G: S32212, a novel serotonin type $2 \mathrm{C}$ receptor inverse agonist/alpha2-adrenoceptor antagonist and potential antidepressant: I. A mechanistic characterization. J Pharmacol Exp Ther 2012, 340:750-764.
55. Odagaki Y, Kinoshita M, Toyoshima R: Functional activation of Galpha via serotonin (5-HT) and muscarinic acetylcholine $M$ receptors assessed by guanosine-5-O-(3-[S]thio)triphosphate ([S]GTPgammaS) binding/immunoprecipitation in rat brain membranes. Eur J Pharmacol 2014, 726C:109-115.

56. Shi J, Zemaitaitis B, Muma NA: Phosphorylation of Galpha11 protein contributes to agonist-induced desensitization of 5-HT2A receptor signaling. Mol Pharmacol 2007, 71:303-313.

57. Shi J, Damjanoska KJ, Singh RK, Carrasco GA, Garcia F, Grippo AJ, Landry M, Sullivan NR, Battaglia G, Muma NA: Agonist induced-phosphorylation of Galpha11 protein reduces coupling to 5-HT2A receptors. J Pharmacol Exp Ther 2007, 323:248-256.

58. Cussac D, Boutet-Robinet E, Ailhaud MC, Newman-Tancredi A, Martel JC, Danty $\mathrm{N}$, Rauly-Lestienne I: Agonist-directed trafficking of signalling at serotonin 5-HT2A, 5-HT2B and 5-HT2C-VSV receptors mediated Gq/11 activation and calcium mobilisation in CHO cells. Eur J Pharmacol 2008, 594:32-38.

59. La Cour Mannoury C, Chaput C, Touzard M, Millan MJ: An immunocapture/ scintillation proximity analysis of $\mathrm{G}$ alpha $\mathrm{q} / 11$ activation by native serotonin $(5-\mathrm{HT}) 2 \mathrm{~A}$ receptors in rat cortex: blockade by clozapine and mirtazapine. Synapse 2009, 63:95-105.

60. Launay JM, Birraux G, Bondoux D, Callebert J, Choi DS, Loric S, Maroteaux L: Ras involvement in signal transduction by the serotonin $5-\mathrm{HT} 2 \mathrm{~B}$ receptor. J Biol Chem 1996, 271:3141-3147.

61. Manivet P, Mouillet-Richard S, Callebert J, Nebigil CG, Maroteaux L, Hosoda S, Kellermann O, Launay JM: PDZ-dependent activation of nitric-oxide synthases by the serotonin 2B receptor. J Biol Chem 2000, 275:9324-9331.

62. Chen $Y$, Baez M, Yu L: Functional coupling of the $5-\mathrm{HT} 2 \mathrm{C}$ serotonin receptor to G proteins in Xenopus oocytes. Neurosci Lett 1994, 179:100-102.

63. Quick MW, Simon MI, Davidson N, Lester HA, Aragay AM: Differential coupling of $\mathrm{G}$ protein alpha subunits to seven-helix receptors expressed in Xenopus oocytes. J Biol Chem 1994, 269:30164-30172.

64. Hartman JL, Northup JK: Functional reconstitution in situ of 5hydroxytryptamine $2 \mathrm{c}(5 \mathrm{HT} 2 \mathrm{c})$ receptors with alphaq and inverse agonism of 5HT2c receptor antagonists. J Biol Chem 1996, 271:22591-22597.

65. Alberts GL, Pregenzer JF, Im WB, Zaworski PG, Gill GS: Agonist-induced GTPgamma35S binding mediated by human 5-HT(2C) receptors expressed in human embryonic kidney 293 cells. Eur J Pharmacol 1999, 383:311-319.

66. Chang M, Zhang L, Tam JP, Sanders-Bush E: Dissecting G protein-coupled receptor signaling pathways with membrane-permeable blocking peptides. Endogenous 5-HT(2C) receptors in choroid plexus epithelial cells. J Biol Chem 2000, 275:7021-7029.

67. Price RD, Weiner DM, Chang MS, Sanders-Bush E: RNA editing of the human serotonin 5 - $\mathrm{HT} 2 \mathrm{C}$ receptor alters receptor-mediated activation of $\mathrm{G} 13$ protein. J Biol Chem 2001, 276:44663-44668.

68. Cussac D, Newman-Tancredi A, Duqueyroix D, Pasteau V, Millan MJ: Differential activation of $\mathrm{Gq} / 11$ and $\mathrm{Gi}(3)$ proteins at 5-hydroxytryptamine(2C) receptors revealed by antibody capture assays: influence of receptor reserve and relationship to agonist-directed trafficking. Mol Pharmacol 2002, 62:578-589.

69. McGrew L, Chang MS, Sanders-Bush E: Phospholipase D activation by endogenous 5 -hydroxytryptamine $2 \mathrm{C}$ receptors is mediated by Galpha 13 and pertussis toxin-insensitive Gbetagamma subunits. Mol Pharmacol 2002, 62:1339-1343.

70. Okada M, Northup JK, Ozaki N, Russell JT, Linnoila M, Goldman D: Modification of human $5-\mathrm{HT}(2 \mathrm{C})$ receptor function by Cys $23 \mathrm{Ser}$, an abundant, naturally occurring amino-acid substitution. Mol Psychiatry 2004, 9:55-64.

71. Ponimaskin EG, Heine M, Joubert L, Sebben M, Bickmeyer U, Richter DW, Dumuis A: The 5-hydroxytryptamine(4a) receptor is palmitoylated at two different sites, and acylation is critically involved in regulation of receptor constitutive activity. J Biol Chem 2002, 277:2534-2546.

72. Pindon A, van Hecke G, van Gompel P, Lesage AS, Leysen JE, Jurzak M: Differences in signal transduction of two 5 -HT4 receptor splice variants: compound specificity and dual coupling with Galphas- and Galphai/oproteins. Mol Pharmacol 2002, 61:85-96.

73. Ponimaskin EG, Profirovic J, Vaiskunaite R, Richter DW, Voyno-Yasenetskaya TA: 5-Hydroxytryptamine 4(a) receptor is coupled to the Galpha subunit of heterotrimeric G13 protein. J Biol Chem 2002, 277:20812-20819.

74. Pellissier LP, Barthet G, Gaven F, Cassier E, Trinquet E, Pin JP, Marin P, Dumuis A, Bockaert J, Baneres JL, Claeysen S: G protein activation by serotonin type 4 receptor dimers: evidence that turning on two protomers is more efficient. J Biol Chem 2011, 286:9985-9997.

75. Francken BJ, Josson K, Lijnen P, Jurzak M, Luyten WH, Leysen JE: Human 5-hydroxytryptamine $(5 \mathrm{~A})$ receptors activate coexpressed $\mathrm{G}(\mathrm{i})$ and 
G(o) proteins in Spodoptera frugiperda 9 cells. Mol Pharmacol 2000 57:1034-1044.

76. Francken BJ, Vanhauwe JF, Josson K, Jurzak M, Luyten WH, Leysen JE: Reconstitution of human 5 -hydroxytryptamine 5 A receptor-G protein coupling in E. coli and Sf9 cell membranes with membranes from Sf9 cells expressing mammalian G proteins. Receptors Channels 2001, 7:303-318.

77. Noda M, Yasuda S, Okada M, Higashida H, Shimada A, Iwata N, Ozaki N, Nishikawa K, Shirasawa S, Uchida M, Aoki S, Wada K: Recombinant human serotonin $5 \mathrm{~A}$ receptors stably expressed in C6 glioma cells couple to multiple signal transduction pathways. J Neurochem 2003, 84:222-232.

78. Baker LP, Nielsen MD, Impey S, Metcalf MA, Poser SW, Chan G, Obrietan K, Hamblin MW, Storm DR: Stimulation of type 1 and type 8 Ca2+/calmodulinsensitive adenylyl cyclases by the Gs-coupled 5-hydroxytryptamine subtype 5-HT7A receptor. J Biol Chem 1998, 273:17469-17476.

79. Kang H, Lee WK, Choi YH, Vukoti KM, Bang WG, Yu YG: Molecular analysis of the interaction between the intracellular loops of the human serotonin receptor type $6(5-\mathrm{HT} 6)$ and the alpha subunit of GS protein. Biochem Biophys Res Commun 2005, 329:684-692.

80. Adham N, Zgombick JM, Bard J, Branchek TA: Functional characterization of the recombinant human 5-hydroxytryptamine7(a) receptor isoform coupled to adenylate cyclase stimulation. J Pharmacol Exp Ther 1998 287:508-514.

81. Alberts GL, Chio CL, Im WB: Allosteric modulation of the human 5-HT(7A) receptor by lipidic amphipathic compounds. Mol Pharmacol 2001, 60:1349-1355

82. Kvachnina E, Liu G, Dityatev A, Renner U, Dumuis A, Richter DW, Dityateva G, Schachner M, Voyno-Yasenetskaya TA, Ponimaskin EG: 5-HT7 receptor is coupled to $\mathrm{G}$ alpha subunits of heterotrimeric $\mathrm{G} 12$-protein to regulate gene transcription and neuronal morphology. J Neurosci 2005, 25:7821-7830.

83. Kvachnina E, Dumuis A, Wlodarczyk J, Renner U, Cochet M, Richter DW, Ponimaskin E: Constitutive Gs-mediated, but not G12-mediated, activity of the 5-hydroxytryptamine $5-\mathrm{HT7}$ (a) receptor is modulated by the palmitoylation of its C-terminal domain. Biochim Biophys Acta 2009, 1793:1646-1655.

84. Houston C, Wenzel-Seifert K, Burckstummer T, Seifert R: The human histamine H2-receptor couples more efficiently to Sf9 insect cell Gs-proteins than to insect cell Gq-proteins: limitations of Sf9 cells for the analysis of receptor/ Gq-protein coupling. J Neurochem 2002, 80:678-696.

85. Linder ME, Middleton P, Hepler JR, Taussig R, Gilman AG, Mumby SM: Lipid modifications of $\mathrm{G}$ proteins: alpha subunits are palmitoylated. Proc Natl Acad Sci U S A 1993, 90:3675-3679.

86. Lambert NA, Johnston CA, Cappell SD, Kuravi S, Kimple AJ, Willard FS, Siderovski DP: Regulators of G-protein signaling accelerate GPCR signaling kinetics and govern sensitivity solely by accelerating GTPase activity. Proc Natl Acad Sci U S A 2010, 107:7066-7071.

87. Bosch DE, Zielinski T, Lowery RG, Siderovski DP: Evaluating modulators of "Regulator of G-protein Signaling" (RGS) proteins. Curr Protoc Pharmacol 2012, Chapter 2:Unit2 8

88. Millan MJ, Marin P, Bockaert J, Mannoury la Cour C: Signaling at G-proteincoupled serotonin receptors: recent advances and future research directions. Trends Pharmacol Sci 2008, 29:454-464.

89. Moya PR, Berg KA, Gutierrez-Hernandez MA, Saez-Briones P, Reyes-Parada M, Cassels BK, Clarke WP: Functional selectivity of hallucinogenic phenethylamine and phenylisopropylamine derivatives at human 5-hydroxytryptamine (5-HT)2A and 5-HT2C receptors. J Pharmacol Exp Ther 2007, 321:1054-1061.

90. Piva F, Giulietti M, Burini AB, Principato G: SpliceAid 2: a database of human splicing factors expression data and RNA target motifs. Hum Mutat 2012, 33:81-85.

91. Albert PR, Robillard L: G protein specificity: traffic direction required. Cell Signal 2002, 14:407-418.

doi:10.1186/s13041-014-0049-y

Cite this article as: Giulietti et al:: How much do we know about the coupling of G-proteins to serotonin receptors? Molecular Brain 2014 7:49.

\section{Submit your next manuscript to BioMed Central and take full advantage of:}

- Convenient online submission

- Thorough peer review

- No space constraints or color figure charges

- Immediate publication on acceptance

- Inclusion in PubMed, CAS, Scopus and Google Scholar

- Research which is freely available for redistribution 